\title{
Evaluation of Varieties and Planting Dates of Cabbage at Isabela, Puerto Rico ${ }^{1}$
}

\author{
Luis M. Cruz Pérez, Abad Morales and Javier Domenech ${ }^{2}$
}

\begin{abstract}
A series of 12 tests planted at monthly intervals with cabbage hybrids Head Start, King Cole, Market Prize and Market Topper, and the open-pollinated varieties Surehead, Marion Market and Stein's Early Flat Dutch were conducted to evaluate their performance and seasonal effects on yield and quality.

Hybrids Head Start and King Cole were the best producers with average marketable yields of 14.83 and 14.56 tons/acre, respectively, for the year. The best distribution of yield throughout the year was produced by hybrid Head Start which produced over 13 tons/acre of marketable cabbage in 10 out of the 12 trials. The average highest yields from all the varieties were obtained from January and May plantings.

All the varieties produced good quality cabbage based on firmness and average head weight. According to the average number of days that elapsed from transplanting to harvest, the varieties were classified as early, intermediate and late.
\end{abstract}

\section{INTRODUCTION}

Head cabbage production in Puerto Rico, it is generally accepted, requires temperatures ranging from 60 to $75^{\circ} \mathrm{F}$ (4). Its production is limited to the cooler months of the year for this reason and concentrated in the area around Orocovis (3).

During fiscal year 1970-71, local production of cabbage was 3,300 tons, while imports were estimated at about 3,000 tons (1). These figures point to the potential of increasing cabbage production for satisfying local demand.

Expansion of commercial production of cabbage requires high yielding, good quality and well-adapted varieties. Seed for cabbage grown in the island is produced in the United States. This demands continuous testing for yield, quality and seasonal behavior of promising varieties and hybrids in the potential cabbage producing areas of the island.

This paper presents the results of a series of trials conducted to evalu-

${ }^{1}$ Manuscript submitted to Editorial Board December 12, 1974.

${ }^{2}$ Professor and Plant Physiologist, Assistant Plant Breeder, and Research Assistant, respectively, College of Agriculture and Agricultural Experiment Station, Mayagüez Campus, University of Puerto Rico, Río Piedras, P.R. 
ate a group of cabbage hybrids and open-pollinated varieties and to determine seasonal effects on yield and quality.

\section{MATERIALS AND METHODS}

A series of 12 experiments planted at monthly intervals with cabbage hybrids Market Prize, Market Topper, King Cole and Head Start, and the open-pollinated varieties Marion Market, Surehead and Stein's Early Flat Dutch were conducted at the Isabela Substation from October 1970 to September 1971. Each of these experiments consisted of seven varieties replicated four times in randomized complete block designs. The experimental plot area in all experiments was $6 \times 40 \mathrm{ft}$ and the planting distance was 9 in between plants and $3 \mathrm{ft}$ between rows.

The experiments were laid out on Coto clay, a typical clay soil of the Isabela area. The precipitation and temperature that prevailed during the period covered by these experiments are presented and compared with the normal conditions of the area (table 1 ).

In accordance with customary practice in Puerto Rico, the plants were started in seedbeds and transplanted to the field about 30 days after the seeding date.

Each experiment was fertilized before transplanting at a rate of 200 , 200 , and $160 \mathrm{lb} /$ acre of $\mathrm{N}, \mathrm{P}_{2} \mathrm{O}_{5}$, and $\mathrm{K}_{2} \mathrm{O}$, respectively. After transplanting, each experiment was irrigated twice a week for the first 2 weeks and

TABLE 1.-Rainfall and mean temperature observed from October 1970 to November 1971 as compared to the normal conditions for the Isabela Agricultural Experiment Substation'

\begin{tabular}{|c|c|c|c|c|c|c|}
\hline \multirow{2}{*}{ Month } & \multicolumn{3}{|c|}{ Rainfall (Inches) } & \multicolumn{3}{|c|}{ Mean temperature $\left({ }^{\circ} \mathrm{F}\right)$} \\
\hline & $\begin{array}{l}\text { Average } \\
\text { (42yrs) }\end{array}$ & $\begin{array}{l}\text { Observed } \\
(1970-71)\end{array}$ & Deviation & $\begin{array}{c}\text { Average } \\
(12 \mathrm{yrs})\end{array}$ & $\begin{array}{l}\text { Observed } \\
(1970-71)\end{array}$ & Deviation \\
\hline October & 6.41 & 7.73 & 1.32 & 78.33 & 77.54 & -.79 \\
\hline November & 6.18 & 12.26 & 6.08 & 76.42 & 75.71 & -.71 \\
\hline December & 4.74 & 10.70 & 5.96 & 74.17 & 74.36 & .19 \\
\hline January & 3.62 & 4.22 & .60 & 73.08 & 73.35 & .27 \\
\hline February & 3.15 & 5.30 & 2.15 & 73.08 & 72.40 & -.68 \\
\hline March & 3.39 & 5.17 & 1.78 & 74.17 & 71.45 & -2.72 \\
\hline April & 4.98 & 7.36 & 2.38 & 75.42 & 74.23 & -1.19 \\
\hline May & 8.14 & 11.94 & 3.80 & 76.58 & 76.60 & .02 \\
\hline June & 7.34 & 3.64 & -3.70 & 77.58 & 75.70 & -1.88 \\
\hline July & 4.85 & 4.48 & -.37 & 78.50 & 79.06 & .56 \\
\hline August & 6.16 & 3.94 & -2.22 & 78.58 & 78.09 & -.49 \\
\hline September & 6.42 & 5.59 & -.83 & 78.33 & 78.18 & -.15 \\
\hline October & 6.41 & 6.99 & .58 & 78.33 & 76.94 & -1.39 \\
\hline November & 6.18 & 6.47 & .87 & 76.42 & 75.40 & -1.02 \\
\hline
\end{tabular}

${ }^{1}$ Data from the weather station at Isabela Agricultural Experiment Substation. 
thereafter once a week or when necessary. For the control of weeds Dacthal $W 75^{3}$ was used as a preemergent herbicide, followed by hand weeding as required.

Each experiment was sprayed weekly with Diazinon AG 500 and Dithane M 45 to control insects and diseases. For soil insects a bait of Dylox was applied to each experiment immediately after transplanting.

Data on yield, average head weight, firmness (based on a head density test), and earliness were obtained from each variety in each of the 12 experiments. The firmness of the heads was measured by determining their density using a modification of the method described by Pearson (2). All data were subjected to appropriate statistical analyses.

\section{RESULTS AND DISCUSSION}

\section{MARKETABLE YIELD AND PLANTING DATE}

Marketable yields (heads weighing over $1 \mathrm{lb}$ and having no appreciable blemishes) obtained from the seven varieties planted over a 1-year period, are shown in table 2. These data show significant yield differences among the varieties in planting dates, but the best producers were the hybrid varieties and the open-pollinated variety Surehead.

The average marketable yields of all the varieties indicate that January and May plantings produced higher yields than the other monthly plantings. However, the data show that the hybrid varieties produced relatively high yields throughout the year. For example, hybrid Head Start produced over 13 tons/acre of marketable cabbage in 10 out of 12 monthly plantings.

These data also show that the varieties tested, particularly the hybrids, surpassed in each of the monthly plantings the average yield of marketable cabbage per acre in Puerto Rico, which is estimated at about 6.5 tons (1).

\section{CULL YIELDS AND PLANTING DATE}

The data in table 3 show significant differences among the varieties in the yield of cull grade cabbage for most of the planting dates, but the average production of culls for the year indicates that the hybrids produced significantly less culls than the open-pollinated varieties. Hybrid Market Prize, which showed an excellent holding ability, produced an average of only 0.87 ton/acre of culls throughout the year.

The high yields of culls of the open-pollinated variety Marion Market

\footnotetext{
${ }^{3}$ Trade names are used in this publication solely for the purpose of providing specific information. Mention of a trade name does not constitute a guarantee, warranty, or endorsement by the Agricultural Experiment Station indicating superiority to other similar products not mentioned.
} 
TABLE 2.-Marketable yields (tons per acre) produced by seven cabbage varieties planted monthly over a 1-year period at Isabela, P.R.

\begin{tabular}{|c|c|c|c|c|c|c|c|c|c|c|c|c|c|}
\hline Variety & Oct. & Nov. & Dec. & Jan. & Feb. & Mar. & Apr. & May & Jun. & Jul. & Aug. & Sept. & $\begin{array}{l}\text { Average } \\
\text { for } \\
\text { variety }\end{array}$ \\
\hline Head Start & $11.34^{*}$ & 15.75 & 15.75 & $16.84^{*}$ & $15.81^{*}$ & $16.32^{*}$ & $12.98^{*}$ & $17.25^{*}$ & $15.37^{*}$ & $16.17^{*}$ & $13.79^{*}$ & $12.81^{*}$ & $14.83^{*}$ \\
\hline King Cole & $12.47^{*}$ & $19.18^{*}$ & $19.18^{*}$ & $19.45^{*}$ & $16.60^{*}$ & 12.52 & $12.22^{*}$ & $16.59^{*}$ & $13.59^{*}$ & 12.35 & $14.47^{*}$ & 11.33 & $14.56^{*}$ \\
\hline Market Prize & $13.61^{*}$ & 15.41 & 15.41 & $17.98^{*}$ & 13.40 & 11.21 & $10.38^{*}$ & $-7.75^{*}$ & $12.76^{*}$ & $13.84^{*}$ & 11.59 & $12.95^{*}$ & $13.87^{*}$ \\
\hline Market Topper & $12.65^{*}$ & 14.64 & 14.64 & $17.36^{*}$ & 13.49 & 12.19 & $11.98^{*}$ & $17.92^{*}$ & $12.73^{*}$ & $14.00^{*}$ & $12.16^{*}$ & $13.80^{*}$ & $13.86^{*}$ \\
\hline Surehead & 6.12 & 14.29 & 14.29 & $20.02^{*}$ & $15.14^{*}$ & 10.77 & $12.71^{*}$ & $16.66^{*}$ & $13.87^{*}$ & $13.22^{*}$ & 11.59 & $12.50^{*}$ & $13.68^{*}$ \\
\hline Stein's E.F.D. & 9.63 & 14.04 & 14.04 & $19.80^{*}$ & 12.71 & 8.66 & $10.92^{*}$ & $11.89^{*}$ & $11.07^{*}$ & 9.61 & 10.49 & 8.98 & 11.96 \\
\hline Marion Market & 7.05 & 12.76 & 12.76 & 12.54 & 11.29 & 10.60 & 8.17 & 11.04 & 10.55 & 10.51 & 10.00 & 9.95 & 10.29 \\
\hline Average/month & 10.26 & 14.35 & $15.15^{*}$ & $17.71^{*}$ & 14.06 & 11.75 & 11.23 & $15.58 *$ & 12.84 & 12.81 & 12.01 & 11.76 & 13.29 \\
\hline
\end{tabular}

* Asterisks denote highest yields which do not differ significantly among themselves at the $1 \%$ level. 
TABLE 3.-Yields of cull grade cabbage (tons per acre) produced by seven cabbage varieties planted monthly over a 1-year period at Isabela, Puerto Rico

\begin{tabular}{|c|c|c|c|c|c|c|c|c|c|c|c|c|c|}
\hline Variety & Oct. & Nov. & Dec. & Jan. & Feb. & Mar. & Apr. & May & Jun. & Jul. & Aug. & Sept. & $\begin{array}{c}\text { Average } \\
\text { for } \\
\text { variety }\end{array}$ \\
\hline Head Start & 3.70 & 4.20 & 1.37 & 0.91 & 0.18 & 0.53 & 1.75 & 0.94 & 1.07 & 0.26 & 0.62 & 0.83 & 1.36 \\
\hline King Cole & $4.17^{*}$ & 3.38 . & 1.60 & 1.16 & $.88^{*}$ & 1.21 & 1.60 & .87 & 1.37 & 1.18 & 1.11 & 1.31 & 1.65 \\
\hline Market Prize & 1.27 & 1.44 & .47 & 1.32 & .54 & 1.03 & 1.95 & .34 & .78 & .27 & .70 & .43 & .87 \\
\hline Market Topper & $3.81^{*}$ & 1.98 & 1.96 & 2.09 & $1.40^{*}$ & 1.10 & 2.16 & .21 & 1.00 & .54 & .96 & .68 & 1.49 \\
\hline Surehead & $3.79^{*}$ & 3.32 & 2.47 & 1.18 & $.98^{*}$ & $2.27^{*}$ & 1.52 & 1.32 & .69 & $1.96^{*}$ & 1.16 & $1.93^{*}$ & $1.88^{*}$ \\
\hline Stein's E.F.D. & $4.11^{*}$ & 4.36 & $2.76^{*}$ & $2.95^{*}$ & $1.04^{*}$ & $1.81^{*}$ & 2.15 & 1.20 & 1.04 & $2.24^{*}$ & $1.86^{*}$ & $2.63^{*}$ & 2.34 \\
\hline Marion Market & $5.31^{*}$ & $7.07^{*}$ & $3.64^{*}$ & $3.00^{*}$ & $1.23^{*}$ & 1.17 & 2.39 & $2.78^{*}$ & .52 & 1.23 & 1.55 & .86 & $2.56^{*}$ \\
\hline Average/month & $3.73^{*}$ & $3.67^{*}$ & 2.03 & 1.80 & 0.89 & 1.30 & 1.93 & 1.09 & 0.92 & 1.09 & 1.13 & 1.23 & \\
\hline
\end{tabular}

* Asterisks denote higher yields of culls which do not differ significantly among themselves at the $1 \%$ level. 
was due to its poor holding ability. Mature heads of this variety are very susceptible to cracking when a dry period is followed by rainfall or irrigation. Varieties Surehead and Stein's Early Flat Dutch produced large heads but they did not head normally and produced very soft heads during the summer or when temperatures were high. These characteristics account for the high production of cull-grade cabbage from these two varieties. The average production of culls by all the varieties for the 12 planting dates indicated that October and November plantings produced significantly higher yields than the rest of the plantings. These two particular plantings were severely affected by the excessive and unusual rainfall at Isabela for the months of October, November and December 1970 (table 1).

\section{QUALITY OF THE MARKETABLE YIELD}

The quality of the marketable yield was measured by the firmness and the average weight of heads. Average head weights over $1.5 \mathrm{lb}$ and a firmness of over 0.5 , based on consumer preferences, were considered good standards of quality. The average performance of the varieties tested with reference to yield and quality is shown in table 4. These data show that all the varieties were within the standards of good quality.

The heads of varieties Stein's Early Flat Dutch and Surehead were significantly heavier than those of the other varieties. However, these two varieties produced significantly less firm heads. The smallest heads, weighing an average of $1.63 \mathrm{lb}$, were produced by the variety Marion Market. This variety, however, produced very firm heads.

TABLE 4.-Average performance of seven varieties of cabbage planted monthly from October 1970 to September 1971

\begin{tabular}{lcccl}
\hline \multicolumn{1}{c}{ Variety } & $\begin{array}{c}\text { Marketable } \\
\text { yield }\end{array}$ & $\begin{array}{c}\text { Average } \\
\text { head weight }\end{array}$ & $\begin{array}{c}\text { Firmness } \\
\text { (head } \\
\text { density) }\end{array}$ & \multicolumn{1}{c}{ Earliness $^{1}$} \\
\hline Head Start & $14.83 \mathrm{a}^{2}$ & $1.87 \mathrm{~b}$ & $0.58 \mathrm{~b}$ & $66-60$ Early \\
King Cole & $14.56 \mathrm{a}$ & $2.00 \mathrm{~b}$ & $.63 \mathrm{a}$ & $65-70$ Intermediate \\
Market Prize & $13.87 \mathrm{ab}$ & $1.74 \mathrm{c}$ & $.62 \mathrm{a}$ & $65-70$ Intermediate \\
Market Topper & $13.86 \mathrm{ab}$ & $1.82 \mathrm{~b}$ & $.67 \mathrm{a}$ & $65-70$ Intermediate \\
Surehead & $13.68 \mathrm{ab}$ & $2.21 \mathrm{a}$ & $.49 \mathrm{c}$ & $75-80$ Late \\
Stein's E.F.D. & $11.96 \mathrm{~b}$ & $2.23 \mathrm{a}$ & $.52 \mathrm{c}$ & $75-80$ Late \\
Marion Market & $10.29 \mathrm{c}$ & $1.63 \mathrm{c}$ & $.60 \mathrm{~b}$ & $55-60$ Early \\
\hline
\end{tabular}

\footnotetext{
${ }^{1}$ Based on average number of days from transplanting to harvest.

${ }^{2}$ Any two means in any column with the same letter are not significantly different at the $1 \%$ level.
} 
EARLINESS

The varieties were classifed as early, intermediate, and late, according to the average number of days that elapsed from transplanting to harvest. Varieties Head Start and Marion Market, with an average of 55-60 days, were classified as early. Market Prize, Market Topper, and King Cole, with an average of 65-75 days, were classified as intermediate, while varieties Surehead and Stein's Early Flat Dutch, with an average of 75-80 days, were classified as late.

The results of these experiments show that the hybrid varieties tested, regardless of planting date, surpassed the average yield per unit area of head cabbage in Puerto Rico. This indicates the possibility of producing high yields of good quality cabbage throughout the year under irrigation in the Isabela region using any of the hybrids tested. Further trials of a similar nature should be carried out to test the adaptability and seasonal performance of these and other promising varieties and hybrids in the cabbage producing areas of the island.

\section{RESUMEN}

Los híbridos de repollo Head Start, King Cole, Market Prize y Market Topper y las variedades de polinización libre Surehead, Marion Market y Stein's Early Flat Dutch se evaluaron en la Subestación Agrícola de Isabela. Una serie de 12 experimentos sembrados mensualmente con este grupo de variedades de repollo se realizaron desde octubre de 1970 hasta septiembre de 1971. Se obtuvieron datos de producción, peso medio por cabeza, firmeza y precocidad de las variedades.

Las variedades híbridas Head Start y King Cole produjeron los rendimientos anuales más altos con producciones medias de 14.83 y 14.56 toneladas por acre, respectivamente. Los rendimientos medios más altos de todas las variedades se obtuvieron en las siembras de enero y mayo. La mejor distribución anual de la producción la produjo la variedad Head Start, que produjo más de 13 toneladas por acre de repollo comercial en 10 de las 12 pruebas.

Con respecto a la firmeza y al peso medio de los repollos, todas las variedades produjeron repollos de buena calidad. Estas se clasificaron como tempranas, intermedias y tardras, según los dfas transcurridos entre el trasplante y la cosecha.

\section{LITERATURE CITED}

1. Anonymous, Anuario de Estadísticas Agrícolas de Puerto Rico, 1970-71, Departamento de Agricultura, E.L.A. de Puerto Rico, 1972.

2. Pearson, O. H., Methods for determining the solidity of cabbage heads, Hilgardia 5: 382-93, 1931.

3. Osuna, P., El cultivo de hortalizas, Revista de Agricultura de Puerto Rico 51(2): 15-39, 1964.

4. Winters, H. F., and Miskimen, G. W., Vegetable gardening in the Caribbean Area, USDA Handbook 323, 1967. 